\title{
体幹ギプス固定による高齢者脊椎圧迫骨折の治療
}

\author{
新小倉病院整形外科 \\ 後藤誠・福 田文 雄 \\ 益 本 真太郎・肱 岡 昭 彦
}

\section{Treatment of Vertebral Compression Fracture by Body Cast}

\author{
Makoto Gotoh, Fumio Fukuda, Shintaro Masumoto, \\ and Akihiko Hijioka
}

Department of Orthopaedic Surgery,

Shinkokura Hospital, Fukuoka, Japan

\begin{abstract}
Vertebral compression fracture in patients of advanced age is disadvantage as it forces long term rest. Recently some surgical treatments have been reported. We have been treating vertebral compression fracture by body cast and good results have been achieved.

In this study, the subjects comprised of 44 females and 8 males with a mean age of 77.7 years (range: 58 to 92 years) treated by body cast within two weeks from injury.

We evaluated patient pain according to VAS (Visual Analogue Scale) and recorded days when patients could sit on a wheel chair, walker gait, and T-cane gait.

Results were as follows: (1) the average VAS when patients were admitted to our hospital was 7.5, three days later was 5.4, one week later was 4.6, two weeks later was 3.0 and when discharged was 1.2; (2) the average days the patients could sit on a wheel chair was 4.3 days, walker gait was 6.8 days, and T-cane gait was 12.2 days; (3) the average VAS of posterior wall damaged cases was higher than non-damaged cases; (4) the average days of admission of posterior wall damaged cases was longer than non-damaged cases.
\end{abstract}

Key words : vertebral compression fracture (春椎圧迫骨折), conservative treatment (保存 治療), old age (高齢者), osteoporosis (骨粗鬆症), body cast（体幹ギプス）

\section{は じめに}

脊椎圧迫骨折は腰背部痛のため, 長期臥床を余儀な くされることが多い。長期間の臥床は高齢者にとって 不利益であり, 早期離床の目的で手術療法が散見され るようになっだ". しかし, 我々は脊椎圧迫骨折に対 し体幹ギプス固定を行い, 良好な成績を得ている.

そこで, 我々は受傷後早期に体幹ギプス固定を行っ た脊椎圧迫骨折患者の疼痛スコア (Visual Analogue Scale；VAS）と運動機能レベルの経時的変化を明ら かにし, また, 椎体後壁の損傷の有無により, VAS 及び入院期間の経時的変化に差があるか否かを検討し たので報告する.

\section{対象と方法}

対象は, 受傷後 2 週以内に, 体動困難は為入院とな り，体幹ギプス固定を行った 52 例．女性 44 例・男性 8 例, 年齢は 58 92 歳 (平均年齢 77.7 歳), 入院期 間は $6 〜 62$ 日（平均 26 日）であった。

体幹ギプス固定は立位で行い, 固定後は疼痛に応じ て日常生活を許可し, 自信がつけば自宅退院とした. 3 週間固定を原則とし, その後は軟性コルセット装着 へと切り換え, 2 ケ月間の装着を指示した（図 1 ).

\section{検 討 項 目}

(1)入院時, 3 日後, 1 週後, 2 週後, 3 週後, 4 週後, 
・体幹ギプスの固定期間は3週

•軟性コルセット装着期間は2ヶ月を原則
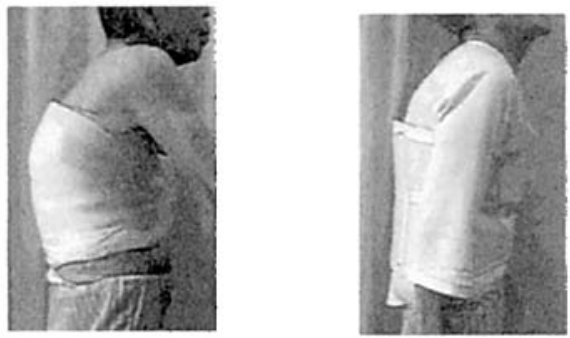

図 1 方法

体幹ギプス固定は，受傷後 2 週以内に行い体幹 ギプス固定は約 3 週間固定を原則とした．その 後は軟性コルセット装着へと切り替え，2 ケ月 間の装着を指示した.

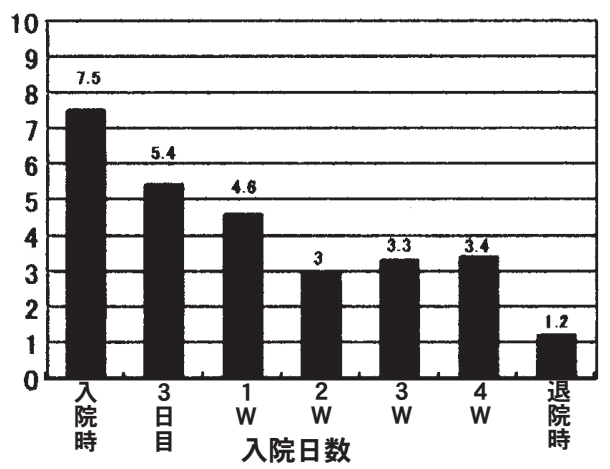

図 $2 \mathrm{VAS}$ の経時的変化 入院時 VAS は徐々に低下した.

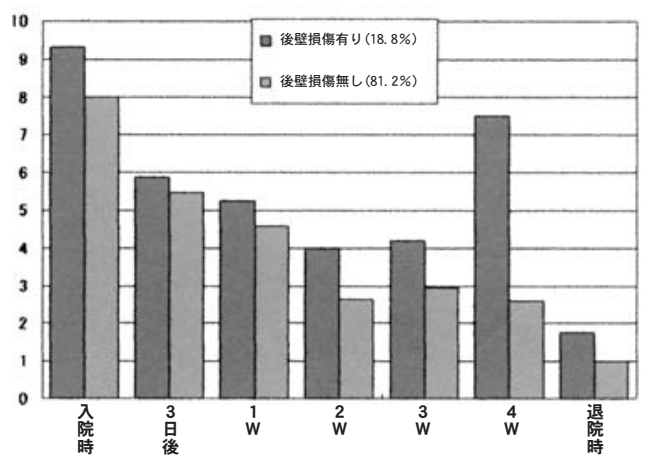

図 4 椎体後壁損傷の有無によるVAS の比較 椎体後壁損傷有り群は無し群に比べ VAS は高 $<$, 疼痛軽減は遅延化した。
退院時の VAS を記録した. (2)運動機能の評価として, 車椅子・歩行器・ $\mathrm{T}$ 杖歩行可能となるまでに要した日 数を記録した. (3) MRI にて罹患椎体の後壁損傷の有 無を確認し, VAS の推移と入院日数を比較した.

$$
\text { 結果 }
$$

(1)入院時平均 VAS は 7.5 であつたが，3 日後には 5.4，1 週後には 4.6, 2 週後には 3 まで低下した. 3 週，4 週後にはそれぞれ $3.3 ， 3.4$ と VAS の軽度上昇 を認めたが，退院時には 1.2 までに低下した（図 2).

(2)各運動機能レベルについて，車椅子可能となるま でに要した日数は平均 4.3 日, 歩行器歩行に移行でき るまでに要した日数は 6.8 日， $\mathrm{T}$ 杖歩行可能となるま でに要した日数は 12.2 日であった（図 3 ).

(3)椎体の後壁損傷の有無での VAS の比較を行うと,

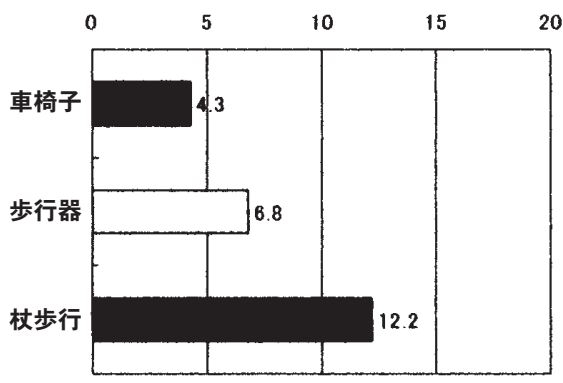

図 3 各運動レベル可能となるまでに要した日数 車椅子に移動できるまでに要した日数は平均 4.3 日, 歩行器歩行可能となるまでに要した日 数は平均 6.8 日, 杖歩行可能となるまでに要し た日数は平均 12.2 日であった.

(日)

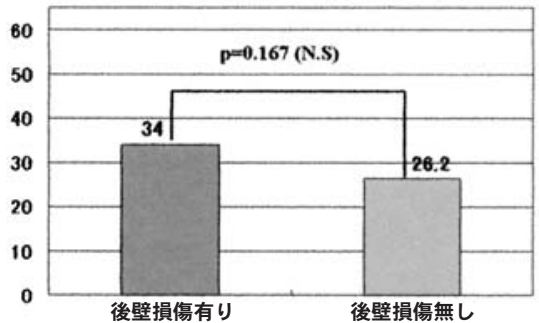

図 5 椎体後壁損傷の有無による入院期間 後壁損傷有り群は無し群に比し, 入院期間が長 くなる傾向にあった. 
後壁損傷有り群の疼痛スコアは, 後壁損傷無し群に比 ベ高く, 疼痛軽減が遅延化していた（図 4).

(4)椎体の後壁損傷の有無での入院日数の比較を行う と, 後壁損傷有り群は平均 34 日, 後壁損傷無し群は 26.2 日と, 有意差は認めなかったものの, 有り群が 長くなる傾向にあった（図 5).

\section{考察}

骨折治療の基本原則は初期に強固な固定と安静を行 うことであるが，椎体骨折に関しても例外ではない. 初期固定として, ギプスでの固定力は他の硬性・軟性 コルセットと比較し, 強度であることは疑いない. 疼 痛が強ければ，ベッド上安静期間が長くなるとの報告 がある23). 長期臥床が廃用を引きおこすとの明らかな 根拠はないが，早期に離床でき，日常生活ができるよ うになるに越したことはない. 内科的問題を抱えてい たり，高度肥満・高度亀背症例等，体幹ギプス固定が 困難な例を除けば，高齢者とはいえギプス固定は可能 であり，早期に離床することが可能である。しかし， 初期固定が不十分であれば疼痛は遷延化し，偽関節に なりうる3).

今回, 我々は受傷後早期に体幹ギプス固定を行うこ とで疼痛の軽減が得られ，VAS 值は低下し，運動機 能レベルは改善した。見松・吉田ら²)が報告した脊椎 圧迫骨折の VAS 值の推移も同様に低下する傾向をみ せた．我々のデータでは 3 週後に疼痛スコアの上昇を 認めた.これは, 体幹ギプス除去に伴う疼痛の再燃と 思われ，特に椎体後壁損傷群においてはその傾向が顕 著であつた.

後壁損傷有り群は, 無し群よりも疼痛残存傾向にあ り，このことは骨癒合に時間を要することを示してお り, 中野，吉田ら ${ }^{23)}$ は, $\mathrm{MRI} ・ \mathrm{CT}$ 等の画像を用い, 治癒過程を経時的に観察している. その報告の中で, 疼痛軽減期間を後壁損傷の有無により比較し, 中野ら は後壁損傷有り群の疼痛軽減期間が 31.6 日（無し群 10.3〜19.6 日)，吉川らは有り群の疼痛消失期間が 70.0 日（無し群 46〜 58 日），演者らは有り群の入院 期間が 34.0 日（無し群 26.2 日）と, 無し群よりも疼
表 1 椎体後壁損傷の有無による疼痛軽減期間 中野らは疼痛軽減期間を吉川・浦山らは疼痛消 失期間を演者らは入院期間を後壁損傷の有無に より比較し, いずれも有り群が, 無し群に比し, 疼痛軽減期間が長くなる結果を得た。

\begin{tabular}{c|c|c}
\hline \hline & 無し群 & 有り群 \\
\hline 中野 & $10.3 \sim 19.6$ 日 & 31.6 日 \\
(軽減期間) & & \\
吉川・浦山 & $46 \sim 58$ 日 & 70 日 \\
(消失期間) & & $(43 \sim 129$ 日 $)$ \\
演者ら & 26.2 日 & 34.0 日 \\
(入院期間) & & \\
\hline
\end{tabular}

痛軽減期間が遅延する結果を得た（表 1 ）。早期に体 幹ギプス固定することにより，良好な成績が得られて いる反面，後壁損傷の一部に，3 週間の体幹ギプス固 定のみでは治癒困難な例があることも示唆された ${ }^{5}$.

\section{結語}

(1)今回我々は, 脊椎圧迫骨折受傷後 2 週間以内に体 幹ギプス固定を行い，疼痛は軽減し，早期に離床する ことができた.

(2)椎体後壁損傷有り群は, 疼痛軽減が遅延し, 入院 期間も長い傾向があった.

\section{参 考 文 献}

1）平泉 裕：麻舫のない骨粗鬆症性脊椎圧迫骨折の治療 一有痛性椎体偽関節に対する椎体ブロック療法．別冊整 形外科, $37: 185-189,2004$.

2）見松健太郎，吉田 徹：春椎圧迫骨折の疼痛評価之保 存療法のクリニカルパス。関節外科, $23(3): 45-49$, 2004.

3）南里泰弘ら：新鮮脊椎圧迫骨折に対する経皮経椎弓根 的燐酸カルシウム骨ペース卜椎体内注入療法。骨折， 25 (1) : 390-396, 2003.

4）中野哲雄ら：麻㽻のない骨粗鬆症の圧迫骨折はどのよ うに治療すべきか. 別冊整形外科, $37: 177-180,2004$.

5）吉岡 啓，浦山茂樹：後壁損傷を伴った骨粗鬆症性脊 椎圧迫骨折の経時的画像変化. 関節外科, 23 (3) : 37-44, 2004. 